\title{
IN SITU IMMOBILIZATION OF COPPER, ZINC AND LEAD POLLUTED SOILS.
}

Abdel-Hamid, M.A ${ }^{1}$; M. M. Kamel' ${ }^{1}$; Samira E. Mahrous ${ }^{2}$ and Omnia, A. Farouk ${ }^{2}$

1 Soil Sci. Dep., Fac. Agric., Cairo University, Giza, Egypt .

2 Soil, Water and Environment Research Institute, ARC, Giza, Egypt

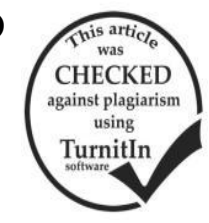

\section{ABSTRACT}

In situ immobilization technique. Two rates $(0.5$ and $1.0 \%)$ of five immobilizing agents (hydrogel, polymer, zeolite, mud and geothite) were used for remediation of $\mathrm{Cu}, \mathrm{Zn}$ and $\mathrm{Pb}$ polluted soils. Three soils containing various levels of $\mathrm{Cu}(66.9-82.9$ $\mathrm{ug} / \mathrm{g}), \mathrm{Zn}(150-328.0 \mathrm{ug} / \mathrm{g})$ and $\mathrm{Pb}(59.7-181 \mathrm{ug} / \mathrm{g})$ were used. Incubation experiment was conducted to study the effect of these agents on soil available content of $\mathrm{Cu}, \mathrm{Zn}$ and $\mathrm{Pb}$. All immobilizing agents reduced the amount of DTPA available of these metals. The addition of 0.5 and $1 \%$ application rate of all agents was sufficient to decrease the DTPA extractable Cu by more than 50\% compared to the untreated soils. The DTPA extractable Zn decreased by values ranged between 39.6-86.7\% and 49.3 to $92.6 \%$ for soils treated with 0.5 and $1 \%$, respectively compared to untreated soils. The available $\mathrm{Pb}$ values was decreased by 44.7-57.8 and 47.5-75.4\% compared to untreated soils at application rate $0.5 \%$ and $1 \%$, respectively. The ability of these agents in immobilizing $\mathrm{Cu}, \mathrm{Zn}$ and $\mathrm{Pb}$ increased with increasing their rate of application and could be arranged as follows :

Zeolite $>$ Polymer $>$ Goethite $>$ Mud $>$ Hydrogel for $\mathrm{Cu}$

Hydrogel $>$ Mud $>$ Goethite $>$ Polymer $>$ Zeolite for $\mathrm{Zn}$

Hydrogel $>\mathrm{Mud}>$ Zeolite $>$ Goethite $>$ Polymer for $\mathrm{Pb}$ in the tested three soils.

Keywords: heavy metals, remediation, immobilization, Copper, Zinc and Lead

\section{INTRODUCTION}

The contamination of soils with toxic heavy metals is responsible for several environmental problems and risk to human health. Elevated concentration of heavy metals in soils can affect flora, fauna and human living. Metal contaminated soils could be remediated by chemical, physical and biological techniques Remediation strategies for metal contaminated sites may incorporate several distinct technology options assembled into a treatment train to attain specific site cleanup goals .These technologies could be grouped into two categories, ex-situ remediation techniques, and in situ fixation of heavy metal using exterior amendments which is a promising technology for cleaning up contaminated soils and wastes.

Stabilization and immobilization of metals in soil are very promising techniques because of their simplicity , high effectiveness, in situ applicability and low cost (Guo et al., 2006).

In situ chemical fixation, involves the use of specific chemical amendments to induce chemical reactions that provide for long-term immobilization of the contaminant without substantially altering the soil properties. On the other hand, in situ remediation approach creates a final solution that is protect human health and the environment. Stabilization is a remediation technology based on adding easily available amendments to polluted soil (e.g. cement, apatite, zeolites, lime), in order to reduce the mobility and bioavailability of metals in the soil without altering their total concentration (Friesl-Hanl et al., 2009; Lee et al., 2009).

Aboulroos et al., (2006) tested three rates (0.25, 0.5 and $1.0 \%$ ) of seven immobilizing agents (cement, slag, phosphate rock, bitumen, $\mathrm{Fe}$ - and Al-gels, and $\delta$ $\mathrm{MnO}_{2}$ ) on three soils containing various levels of $\mathrm{Pb}$ ranged between $(48-192.0 \mathrm{ug} / \mathrm{g})$. The effectiveness of the various agents in immobilizing $\mathrm{Pb}$ followed the descending order: bitumen $>$ cement $>$ slag $>\mathrm{Fe}$-gel $>\mathrm{Al}-$ gel $>$ phosphate rock $>\delta-\mathrm{MnO}_{2}$. Cement and phosphate rock fixed $\mathrm{Pb}$ mainly in the carbonate form, whereas the slag, bitumen, Fe-gel, Al-gel and $\delta-\mathrm{MnO}_{2}$ fixed the metal mainly in the oxide form. Aikpokpodion et al., (2012) studied the potential of Sokoto rock phosphate for immobilization of $\mathrm{Cu}$ and $\mathrm{Pb}$ in contaminated soil. They showed that, bioavailable $\mathrm{Cu}$ in soil was reduced by 19 , 35 and $42 \%$ due to application of 20,40 and $60 \mathrm{~g}$ phosphate per $\mathrm{kg}$ soil, respectively, while, $\mathrm{Pb}$ was reduced by 12,23 and $25 \%$, respectively. The application of $20 \mathrm{~g}, 40 \mathrm{~g}$ and $60 \mathrm{~g}$ rock phosphate reduced foliar $\mathrm{Cu}$ by 80,69 and $85 \%$ while foliar $\mathrm{Pb}$ was reduced by 88,89 and 77\%, respectively. Abdel-Hamid et al., (2012) used the immobilization technique for remediation of lead polluted soils. Two rates $(0.5$ and $1 \%)$ of five immobilizing agents (bentonite, barite, kaolinite, dowex and silica-gel) were tested on soils containing various levels of available $\mathrm{Pb}\left(24-77.3 \mathrm{mg} \mathrm{kg}{ }^{-1}\right)$. The DTPA extractable $\mathrm{Pb}$ decreased by values ranged between ( $26.3-70.5) \%$ and (35.4-95.7)\% at the tested two rates $(0.5$ and $1 \%)$,respectively.

This study was undertaken to evaluate the efficiency of five immobilizing agents ( Hydrogel, Polymer, Zeolite, Mud and Geothiteat) at two rates ( 0.5 and $1 \%$ ) to remediate $\mathrm{Cu}, \mathrm{Zn}$ and $\mathrm{Pb}$ in contaminated agricultural soils.

\section{MATERIALS AND METHODS}

\section{Soil}

Three surface soil samples $(0-30 \mathrm{~cm})$ were collected to represent different sources of $\mathrm{Cu}, \mathrm{Zn}$ and $\mathrm{Pb}$ contamination.

1- Sludged contaminated soils:

El-Gabal El-Asfar area : the soil was settled under irrigation with sewage effluents for more than 75 years

2- Industrial contaminated soil:

Mostorod area : the soil is contaminated with the outputs of mining and smelting .

3- Industrial contaminated soil:

Helwan area : the soil is contaminated with industrial sewage of Iron and steal factories. 
The collected soil samples were air-dried and ground to pass through a 2-mm sieve and preserved for the following analysis. Some of physical and chemical characteristics, available and total portions of $\mathrm{Cu}, \mathrm{Zn}$ and $\mathrm{Pb}$ in the studied soils are presented in Table (1).

\section{Immobilizing Agents}

Five immobilizing agents were tested in the present study as follows:

(1) Hydrogel: obtained from the Egyptian starch and yeast company - Alexandria . The grain size ranges from 100 to $500 \mathrm{u}$. The used Hydrogel is characterized by its solubility in both water organic solvents.

(2) Polymer: obtained from Evonik stockhausen Germany . It is insoluble in water and organic solutions; swells to a gel from upon contact with aqueous fluids .

(3) Zeolite: It has the chemical formula $\mathrm{Na}_{2} \mathrm{Al}_{2} \mathrm{Si}_{3} \mathrm{O}_{10^{-}}$ $2 \mathrm{H}_{2} \mathrm{O}$. Obtained from El- Ahram Company. It has a high CEC $216(\mathrm{meq} / 100 \mathrm{~g})$ and the surface area is $31.1 \mathrm{~m}^{2} \mathrm{~g}^{-1}$.

(4) Mud : obtained from the Egyptian Public Authority for Mineral Resources. And The major constituents are Quartz, Montmorillonite, with minor content of Kaolinite.

(5) Geothite: was prepared in the laboratory, according to Schwertmann, and Cornell, (1991). The molecular weight is $88.85 \mathrm{gm}$, with the empirical formula: $\mathrm{Fe}^{3+} \mathrm{O}(\mathrm{OH})$.

Table1. General characteristics, total and available $\mathrm{Cu}, \mathrm{Zn}$ and $\mathrm{Pb}$ contents of the studied soils

\begin{tabular}{lccc}
\hline Location & El-gabal El-Asfar & Mostorod & Helwan \\
\hline \hline Source of pollutants & $\mathrm{S} *$ & $\mathrm{I} * *$ & $\mathrm{I} * *$ \\
$\mathrm{PH}(1: 2.5)$ & 6.4 & 7.5 & 7.6 \\
$\mathrm{EC}(1: 2.5) \mathrm{dS} / \mathrm{m}$ & 1.83 & 1.59 & 5.18 \\
OM\% & 2.8 & 1.3 & 1.4 \\
Total carbonte content\% & 1.04 & 1.39 & 1.0 \\
Sand \% & 69.8 & 17.6 & 33.8 \\
Silt\% & 7.5 & 44.9 & 24.4 \\
Clay\% & 22.7 & 37.5 & 41.8 \\
Textural class & Sandy clay loam & Silty clay loam & Clay \\
Total $\mathrm{Cu}(\mathrm{ug} / \mathrm{g})$ & 66.9 & 82.9 & 60.5 \\
Total $\mathrm{Zn}(\mathrm{ug} / \mathrm{g})$ & 328.0 & 199.0 & 150.0 \\
Total $\mathrm{Pb}(\mathrm{ug} / \mathrm{g})$ & 181.0 & 62.2 & 59.7 \\
DTPA-Cu (ug/g) & 13.9 & 15.22 & 8.92 \\
DTPA-Zn (ug/g) & 47.30 & 22.18 & 4.06 \\
DTPA-Pb (ug/g) & 18.3 & 11.02 & 18.70 \\
\hline
\end{tabular}

*S:Sewage wastes

**:I:Industrial wastes

\section{Immobilization Technique}

Incubation experiment was conducted to evaluate the tested agents to stabilize $\mathrm{Cu}, \mathrm{Zn}$, and $\mathrm{Pb}$ in the studied soils. Each soil under study was amendment with each of the five immobilizing agents with two rates $(0.5$ and $1.0 \%)$. The procedure was as follows: 20 $\mathrm{g}$ of each soil were transferred to $100 \mathrm{ml}$ glass bottle, each bottle received $20 \mathrm{ml}$ of de-ionized water containing the appropriate amount of immobilizing agent. The treated soils were then dried in an oven, at $40 \mathrm{C}^{\circ}$ for $48 \mathrm{hrs}$. then alternatively wet, with $10 \mathrm{ml}$ of de-ionized water. One wetting and one drying formed a cycle. Each soil was subjected to four wetting and drying cycles (for 28 days). Soil moisture content was maintained at $60 \%$ by weight of the water holding capacity during the experiment . with water added every two days. At the end of the incubation period, soils were crushed to pass through a $2 \mathrm{~mm}$ sieve, then analyzed for total, DTPA extractable $\mathrm{Cu}, \mathrm{Zn}$ and $\mathrm{Pb}$.

Analytical Methods

- DTPA extractable $\mathrm{Cu}, \mathrm{Zn}$ and $\mathrm{Pb}$ were extracted as described by Lindsay and Norvell (1978).
- Total contents of $\mathrm{Cu}, \mathrm{Zn}$ and $\mathrm{Pb}$ were extracted by aqua regia $(\mathrm{HCl}, \mathrm{HNO} 3)$ according to the method described by Cottenie et al. (1982). Concentrations of $\mathrm{Cu}, \mathrm{Zn}$ and $\mathrm{Pb}$ of the extracts were measured using Inductively Coupled Plasma (ICP).

- Mechanical analysis was performed according to the pipette method, organic matter by oxidation with dichromate, and total carbonate content gasometrically using a Collins calcimeter (Sparks, 1996). Soil pH was measured in a 1:2.5 soil: water ratio suspension using a glass electrode (Jackson, 1973). Electrical conductivity (EC) was measured in 1: 2.5 soil: water ratio extracts (Black, 1982).

\section{RESULTS AND DISCUSSION}

\section{Total and DTPA extractable $\mathrm{Cu}, \mathrm{Zn}$ and $\mathrm{Pb}$ in the studied soils.}

The values of the studied heavy metals (Table 1) showed that $\mathrm{Zn}$ had the highest values ( total or available) in all the studied samples. Data revealed that, soils of El Gabal El Asfar area showed the highest Zn 
and $\mathrm{Pb}$ contents of total and available. The total values were 328 and $181 \mathrm{ppm}$, Meanwhile the available values available was 47.3 and $18.3 \mathrm{ppm}$ for $\mathrm{Zn}$ and $\mathrm{Pb}$, respectively. As for Copper, the highest total amount was found in soils collected from Mostorod (82 ppm), followed in decreasing order by El Gabal El Asfar ( $66.9 \mathrm{ppm})$, and Helwan (60.5 ppm). The available $\mathrm{Cu}$ content were 15.2, 13.9 and8.9 ppm for Mostorod, El Gabal El Asfar and Helwan, respectively.

2. In situ immobilization treatments of heavy metals:

In this study, five immobilizing agents (Goethite, Polymer, Zeolite, Mud and hydrogel) at rates ( 0.5 and $1 \%$ ) were used to remediate $\mathrm{Cu}, \mathrm{Zn}$ and $\mathrm{Pb}$, in the selected tested polluted soils.

The tested agents showed their ability to reduce the mobile pool of the investigated metals in the studied soils. The magnitude of reduction varied widely according to the type of immobilizing agents and the rate of its addition.

The data presented in Table (2) showed that the effect of the different immobilizing agents on DTPA extractable $\mathrm{Cu}$. The DTPA extractable $\mathrm{Cu}$ values after $0.5 \%$ application rate (Table 2 ), ranged between $4.8-$ $5.65,4.5-6.1$ and $2.85-4.05 \mu \mathrm{g} / \mathrm{g}$ for soils of El Gabal El Asfar, Mostorod and Helwan, respectively. The values was $4.2-4.9,4.0-5.4$ and $1.6-2.22 \mu \mathrm{g} / \mathrm{g}$, for application rate of $1 \%$, respectively. It may be concluded that the addition of $0.5 \%$ and $1 \%$ application rate for all agents were sufficient to decrease the DTPA extractable $\mathrm{Cu}$ by more than $50 \%$ compared with the untreated treatment. It was noticed that using $1 \%$. application rate of the studied agents slightly decreased the DTPA extractable $\mathrm{Cu}$ compared to the $0.5 \%$ application rate.

Table 2 . DTPA extractable $\mathrm{Cu}(\mu \mathrm{g} / \mathrm{g})$ in the studied soil samples before and after treating the soils with five immobilizing agents.

\begin{tabular}{|c|c|c|c|c|c|c|c|}
\hline \multirow[b]{2}{*}{ Location } & \multirow{2}{*}{$\begin{array}{c}\text { Initial } \\
\text { concentration, } \\
\mu \mathrm{g} / \mathrm{g}\end{array}$} & \multirow{2}{*}{$\begin{array}{c}\text { Soil } \\
\text { Application } \\
\text { rates \% }\end{array}$} & \multicolumn{5}{|c|}{ DTPA extractable $\mathrm{Cu} \mu \mathrm{g} / \mathrm{g}$ in soil } \\
\hline & & & Hydrogel & Polymer & Zeolite & Mud & Goethite \\
\hline \multirow{2}{*}{ Al-Gabal Al-Asfar } & \multirow{2}{*}{13.92} & 0.5 & 5.17 & 5.18 & 5.02 & 5.65 & 4.80 \\
\hline & & 1 & 4.85 & 4.90 & 4.70 & 4.90 & 4.20 \\
\hline \multirow{2}{*}{ Mostorod } & \multirow{2}{*}{15.22} & 0.5 & 6.10 & 5.60 & 5.70 & 5.50 & 4.50 \\
\hline & & 1 & 5.40 & 4.00 & 4.20 & 4.80 & 4.00 \\
\hline \multirow{2}{*}{ Helwan } & \multirow{2}{*}{8.92} & 0.5 & 2.90 & 2.85 & 3.59 & 3.30 & 4.05 \\
\hline & & 1 & 2.10 & 1.70 & 1.60 & 2.10 & 2.22 \\
\hline
\end{tabular}

All the tested amendments relatively decreased the mobility of $\mathrm{Cu}$ in the soils under study. The tested immobilizing agents varied in their effect on fixing $\mathrm{Cu}$ (Fig. 1). In general, and for all the studied soils and tested agents, DTPA extractable $\mathrm{Cu}$ decreased by values ranged between 54.6 and $70.4 \%$ for soils treated with application rate of $0.5 \%$ compared to the untreated soils. On the other hand, application of $1 \%$ was rather effective in reducing DTPA $\mathrm{Cu}$ by values ranged between 64.5 to $82 \%$ compared to the untreated treatment.

Application of Zeolite at rate of $1 \%$, decreased DTPA extractable $\mathrm{Cu}$ by values ranged between $66.2-$ $82 \%$ compared to the untreated soil. Zeolite appears to be an effective amendment to stabilize soil polluted with lead, copper and zinc, because of the negatively charged alumino-silicate structure within giving the Zeolite high cation exchange capacity (CEC), and have reduced the transfer of these metals from polluted soil into plants (Gadepalle et al., 2007).

Results indicated that application rate of $1 \%$ Goethite decreased DTPA extractable $\mathrm{Cu}$ by values ranged between 69.8 - $75.1 \%$ compared to the untreated soil samples. The mechanism ascribed to the reductions rate indicating that the goethite surface plays an important role in controlling reduction by forming a monodentate innersphere $\mathrm{Cu}^{2}+$ goethite surface complexes (Rickard, 1974 ).

The application rate of $1 \%$ polymer reduced the DTPA extractable $\mathrm{Cu}$ by values ranged between 64.5
$80.9 \%$. These polymers contain groups, such as carboxyl groups, that are capable of forming bonds with metallic cations, thereby decreasing their bioavailability in soils (De Varennes 2009).

The reduction in DTPA extractable $\mathrm{Cu}$ was 64.5 $-76.5 \%$ with application rate $1 \%$ of either hydrogel or mud. The Hydrogel is a water-swollen, and cross-linked polymeric network, it is a colloidal substance which can form viscous jellylike forms, and characterized by high surface area; therefore, hydrogel can adsorb heavy metals on its surface (Ahmed 2015). While for Mud , the high specific surface area, layered structure, high cation-exchange capacity, etc., have made it excellent, adsorbent materials(Gupta, and Bhattacharyya, 2006).

The reduction of DTPA extractable $\mathrm{Cu}$ with 0.5 addition rate was $59.75-62.54 \%, 62.78-68 \%, 59.9-$ $67.48 \%, 59.41-63.86 \%$, and $54.59-70.43 \%$ for Zeolite, Polymer, Hydrogel, Mud and Goethite, respectively.

The tested agents could be arranged according to their efficiency in immobilizing $\mathrm{Cu}$ as follows: Zeolite> Polymer $>$ Goethite $>$ Mud $>$ Hydrogel.

The DTPA extractable $\mathrm{Zn}$ in the soil treated with $1 \%$ ( Table 3) ranged between $11.5-24.0,7.1-10.0$ and $0.3-0.46 \mu \mathrm{g} / \mathrm{g}$ for soils of El Gabal El Asfar , Mostorod and Helwan, respectively. The mean values at the application rate of $0.5 \%$ was $18.97-25.75,10.0-$ 13.4 and $0.54-0.72 \mu \mathrm{g} / \mathrm{g}$, respectively 

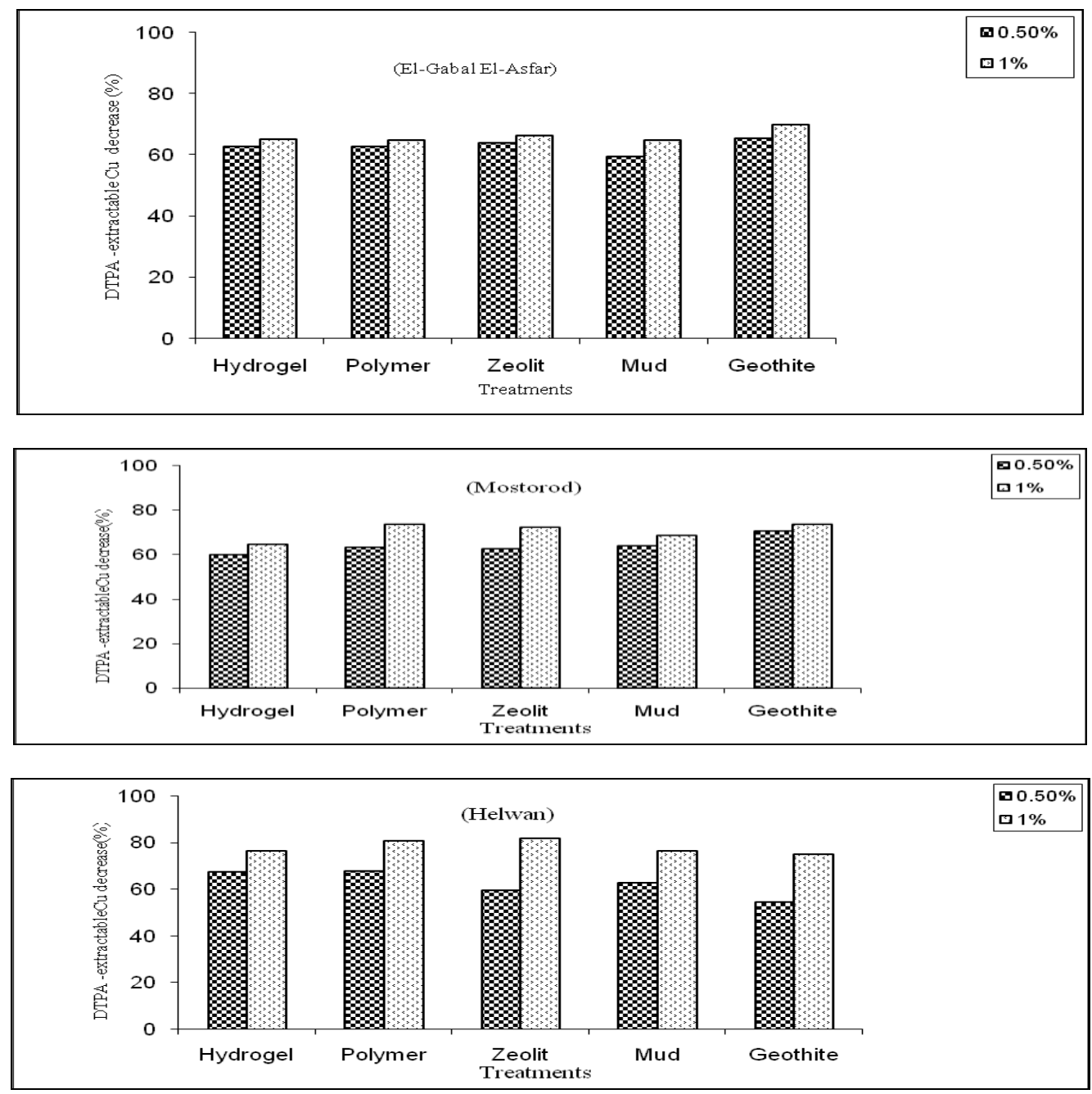

Fig. (1) Effect of different immobilizing agents on DTPA extractable $\mathrm{Cu}$ as a percentage of the initial level.

Table 3 . DTPA extractable $\mathrm{Zn}(\mu \mathrm{g} / \mathrm{g})$ of the studied soil samples before and after treating the soils with five immobilizing agents.

\begin{tabular}{|c|c|c|c|c|c|c|c|}
\hline \multirow[b]{2}{*}{ Location } & \multirow{2}{*}{$\begin{array}{c}\text { Initial } \\
\text { concentration, } \\
\mu \mathrm{g} / \mathrm{g}\end{array}$} & \multirow{2}{*}{$\begin{array}{c}\text { Soil } \\
\text { Application } \\
\text { rates\% }\end{array}$} & \multicolumn{5}{|c|}{ DTPA extractable $\mathrm{Zn} \mu \mathrm{g} / \mathrm{g}$ in soil } \\
\hline & & & Hydrogel & Polymer & Zeolite & Mud & Goethite \\
\hline \multirow{2}{*}{ Al-Gabal Al-Asfar } & \multirow[b]{2}{*}{47.34} & 0.5 & 18.97 & 25.75 & 25.50 & 18.90 & 25.20 \\
\hline & & 1 & 11.50 & 20.50 & 24.0 & 17.80 & 22.10 \\
\hline \multirow{2}{*}{ Mostorod } & \multirow{2}{*}{22.18} & 0.5 & 10.0 & 11.20 & 11.0 & 13.40 & 10.30 \\
\hline & & 1 & 7.90 & 10.0 & 9.10 & 8.00 & 7.10 \\
\hline \multirow{2}{*}{ Helwan } & \multirow{2}{*}{4.06} & 0.5 & 0.72 & 0.61 & 0.54 & 0.61 & 0.57 \\
\hline & & 1 & 0.46 & 0.40 & 0.30 & 0.40 & 0.32 \\
\hline
\end{tabular}

All the amendments relatively decreased the mobility of $\mathrm{Zn}$ in the soils under study. DTPA extractable $\mathrm{Zn}$ decreased by values ranged between 39.6 to $86.7 \%$ for soils treated with application rate of $0.5 \%$ compared to the control treatment. On the other hand, the application rate of $1 \%$ decreased DTPA extractable $\mathrm{Zn}$ by values ranged between 49.3 to $92.6 \%$ compared to the untreated soils. The effect of the tested agents at application rate of $0.5 \%$ and $1 \%$ in reducing DTPA extractable $\mathrm{Zn}$ was $82.3-86.7 \%$ and $85.7-92.6 \%$ respectively in soils of Helwan. These values were 45.6 - 60, and $49.3-75.7 \%$, respectively for soils of El Gabal El Asfar, and 39.5 - 54.9\% and 54.9-67.9\%, respectively for soil of Mostorod.

Results (Fig 2) indicated that application of
Zeolite at rate of $1 \%$ decreased DTPA extractable $\mathrm{Zn}$ by values ranged between 49.3 - $92.6 \%$ compared to the untreated soil. The application rate of $1 \%$ Goethite decreased DTPA extractable $\mathrm{Zn}$ by values ranged between 53.3 - $92.1 \%$ compared to the untreated soil. The corresponding results of adding polymer, hydrogel and mud were: $54.9-90.1 \%, 64.4-88.7 \%$ and $62.4-$ $90.1 \%$, respectively. The reduction of DTPA extractable Zn with 0.5 application rate was $46.1-86.7 \%, 53.6-$ $85.9 \%, 49.5-84.9 \%, 54.9-82.3 \%$ and $39.6-84.9 \%$ compared to the untreated soil for Zeolite, goethite , polymer, hydrogel and mud, respectively.

The tested agents could be arranged according to their efficiency in immobilizing $\mathrm{Zn}$ as follows:

Hydrogel $>$ Mud $>$ Goethite $>$ Polymer $>$ Zeolited 

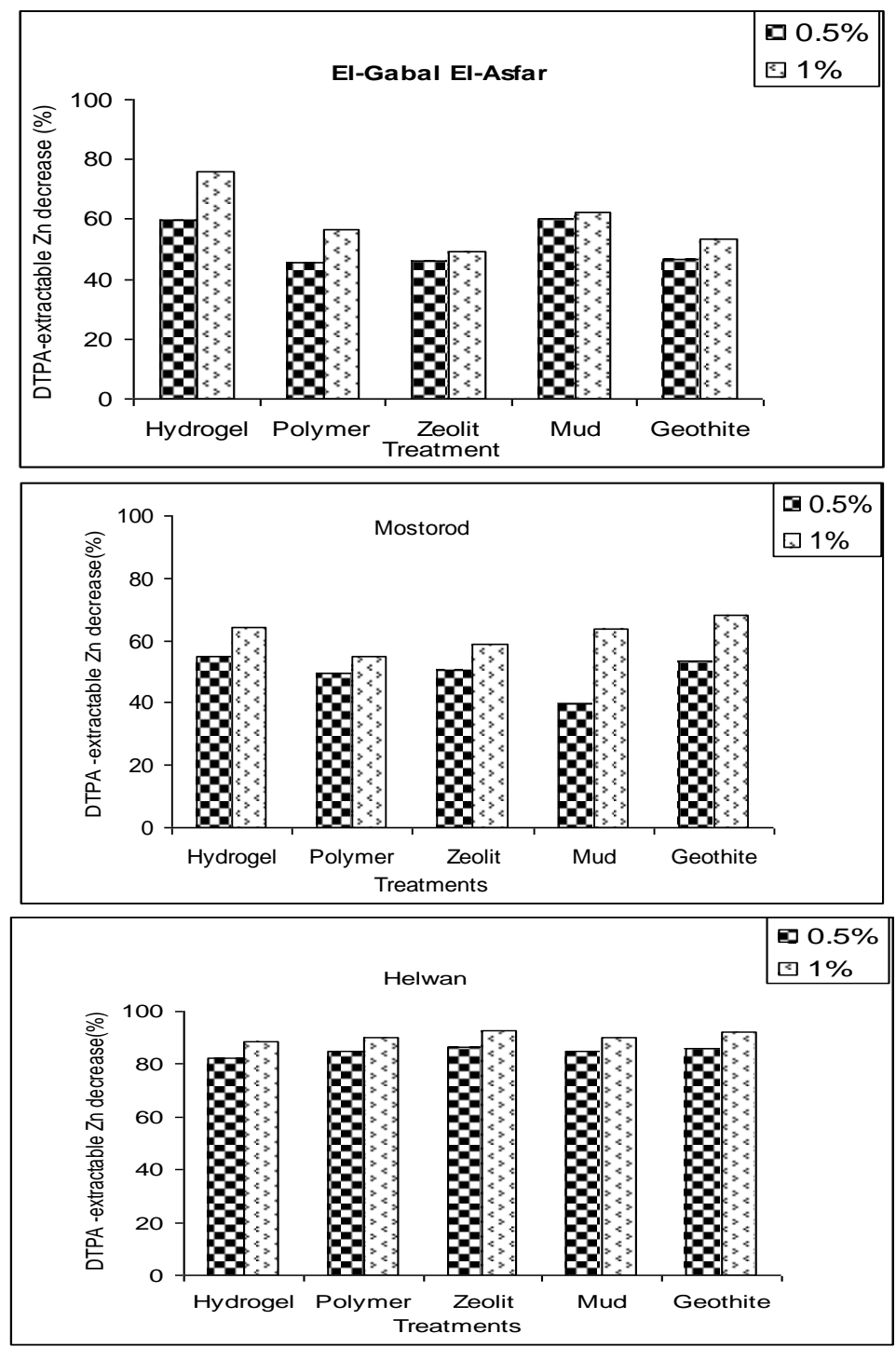

Fig. ( 2 ) Effect of different immobilizing agents on DTPA extractable $\mathrm{Zn}$ as a percentage of the initial level.

Data presented in Table (4) show DTPA extractable $\mathrm{Pb}$ values after treated with immobilizing agents. The DTPA extractable $\mathrm{Pb}$ after treated soils with $0.5 \%$ ranged between $8.4-10.12,5.0-5.8$ and $7.9-$ $9.55 \mu \mathrm{g} / \mathrm{g}$ for soils of El Gabal El Asfar, Mostorod and Helwan, respectively. The corresponding values at the rate of $1 \%$ was $4.5-9.6,4.1-4.5$ and $5.0-7.3 \mu \mathrm{g} / \mathrm{g}$, respectively. It was clear that, using $1 \%$ application rate of the different agents was more effective in decreasing the DTPA extractable $\mathrm{Pb}$ compared to $0.5 \%$ application rate. It could be noticed that the tested amendments decreased the mobility of $\mathrm{Pb}$ in the studied soils and varied in their effect on fixing $\mathrm{Pb}$. In general, and for all soils and all tested agents, DTPA extractable $\mathrm{Pb}$ decreased by values ranged between $44.7-57.8 \%$ for soils treated with application rate of $0.5 \%$ compared to the untreated soils. While the corresponding values at application rate of $1 \%$ recorded reduction ranged between 47.5 and $75.4 \%$.

The results (Fig. 3) indicated that application rate of $0.5 \%$ of Hydrogel, Polymer, Zeolite, Mud and Goethite reduced DTPA extractable Pb by $51-54,44.7$ - 52.4, 47.4 - 57.8, 50.1 - 54 and 8.9 - 51.9\%, respectively. While at the application rate of $1 \%$, the reduction percentage were $60.9-75.4,47.5-73.2$, $57.9-72.2,57.9-73.8$ and $55.7-70.1$, respectively.

Table 4 : DTPA extractable $\mathrm{Pb}(\mu \mathrm{g} / \mathrm{g})$ of the soil samples before and after treating the soils with five immobilizing agents .

\begin{tabular}{lccccccc}
\hline Location & $\begin{array}{c}\text { Initial } \\
\text { concentration, } \\
\boldsymbol{\mu g} / \mathbf{g}\end{array}$ & $\begin{array}{c}\text { Soil Application } \\
\text { rates \% }\end{array}$ & Hydrogel & Polymer & Zeolite & Mud & Goethite \\
\hline \multirow{2}{*}{ Al-Gabal Al-Asfar } & 18.30 & 0.5 & 8.40 & 10.12 & 9.20 & 8.80 & 8.80 \\
\multirow{2}{*}{ Mostorod } & & 1 & 4.50 & 9.60 & 7.70 & 7.70 & 8.10 \\
& 11.02 & 0.5 & 5.40 & 5.70 & 5.80 & 5.50 & 5.00 \\
Helwan & & 1 & 4.10 & 4.50 & 4.40 & 4.10 & 4.40 \\
& \multirow{2}{*}{18.70} & 0.5 & 9.01 & 8.90 & 7.90 & 8.60 & 9.55 \\
& & 1 & 7.30 & 5.01 & 5.20 & 4.90 & 5.60 \\
\hline
\end{tabular}


The tested agents could be arranged according to Hydrogel $>$ Mud $>$ Zeolite $>$ Goethite $>$ Polymer their efficiency in immobilizing $\mathrm{Pb}$ as follows:
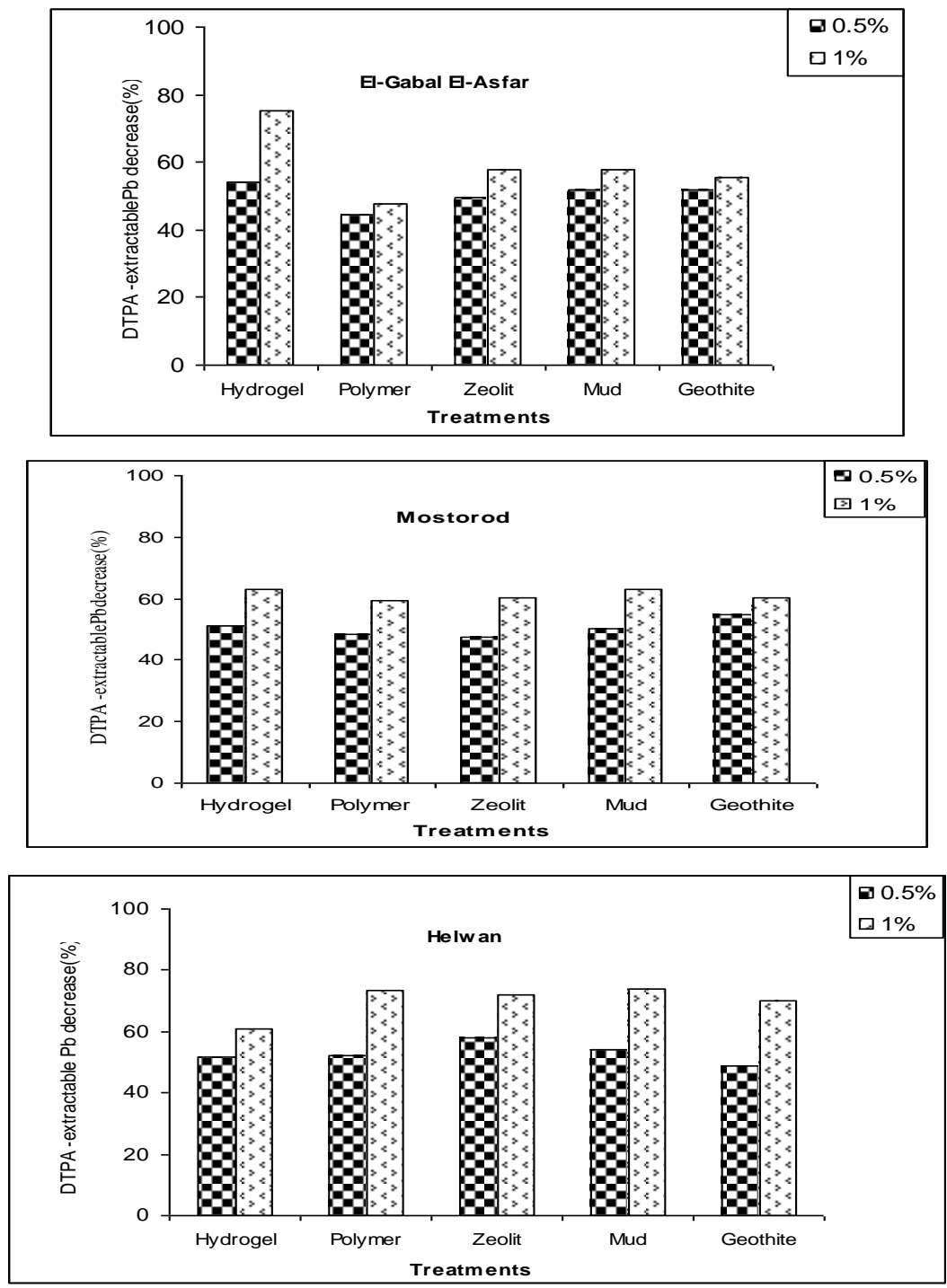

Fig. ( 3 ) Effect of different immobilizing agents on DTPA extractable $\mathrm{Pb}$ as a percentage of the initial level.

\section{CONCLUSION}

Application Hydrogel, Polymer, Zeolite , Mud and Goethite of decreased the mobility of $\mathrm{Cu}, \mathrm{Zn}$ and $\mathrm{Pb}$ in the soils under study. Zeolite appears to be an effective amendment to stabilize soil polluted with lead, copper and zinc. The addition of $0.5 \%$ and $1 \%$ application rate for all agents were sufficient to decrease the DTPA extractable $\mathrm{Cu}$ by more than $50 \%$ compared with the untreated treatment. The addition of $1 \%$ application rate of the different agents was more effective in decreasing the DTPA extractable $\mathrm{Zn}$ and $\mathrm{Pb}$ compared to $0.5 \%$ application rate. The tested agents could be arranged according to their efficiency in immobilizing the tested metals as follows.

Zeolite $>$ Polymer $>$ Goethite $>$ Mud $>$ Hydrogel for $\mathrm{Cu}$ Hydrogel $>$ Mud $>$ Goethite $>$ Polymer $>$ Zeolite for $\mathrm{Zn}$ Hydrogel $>$ Mud $>$ Zeolite $>$ Goethite $>$ Polymer for $\mathrm{Pb}$

\section{REFERENCES}

Aboulroos, S.A., Helal, M.I. and Kamel, M.M.(2006). Remediation of $\mathrm{Pb}$ and $\mathrm{Cd}$ Polluted Soils Using In Situ Immobilization and Phytoextraction.Techniques.Soil and Sediment Contamination, 15:199-215.

Abdel-Hamid, M.A, Kamel, M.M.,Moussa, E.M. and Hoda, A. Refai (2012). In-Situ Immobilization Remediation of Soils Polluted with Lead, Cadmium and Nickel. Global. J. Environ. Res., 6: 1-10.

Aikpokpodion, P.E. , Lajide, L. and Aiyesanmi, A.F. (2012). In Situ Remediation Activities of Rock Phosphate In Heavy-MetaContaminated Cocoa Plantation Soil In Owena, South Western. Nigeria. J. of Environ. Res., 6: 51-57

Ahmed , E. M. (2015). Hydrogel: Preparation, characterization, and applications: A review. Journal of Advanced Research 6: 105-121. 
Black, C.A. (1982). "Methods of Soil Analysis". Amer. Soc. Agron Inc. Ser, 9 in Agron. Madison, Wisconsin, U.S.A.

Cottenie, A., Verloo, M., and Kiekens, L., Velgh, G., and Camcrlynck, R. (1982). Chemical Analysis of Plant And Soils. Lab. Anal., Agrochem., State Univ., Ghent, Belgium.

De Varennes, G. Q. A. (2009). Use of Hydrophilic Insoluble Polymers in the Restoration of MetalContaminated Soils. Applied and Environmental Soil Science., Article ID 790687, 8 pages.

Friesl-Hanl, W. , Platzer, K. and Horak, O. (2009): Immobilising of $\mathrm{Cd}, \mathrm{Pb}$ and $\mathrm{Zn}$ contaminated arable soils close to a former $\mathrm{Pb} / \mathrm{Zn}$ smelter: a field study in Austria over 5 years. Environ. Geochem. Health 31, 581-594.

Gadepalle,V. P., Sabeha, K. O., Ren, V. H., and Tony, H.(2007). Immobilization of Heavy Metals in Soil Using Natural and Waste Materials for Vegetation Establishment on Contaminated Sites. Soil \& Sediment Contamination, 16:233-251.

Guo, G. , Zhou, Q. and Lene, Q. MA. (2006). Availability and assessment of fixing additives for The In Situ Remediation Of Heavy Metal contaminated soils: A Review . Environmental Monitoring and Assessment 116: 513-528.
Gupta, S.S. and K.G. Bhattacharyya, (2006). Removal of Cd (II) from aqueous solution by kaolinite, montmorillonite and their poly (oxo zirconium) and tetrabutylammonium derivatives. J. Hazard. Mater., 128: 247-257.

Jackson, M.L. (1973). "Soil Chemical Analysis". Prentice-Hall, Inc., Englewood Cliffs, N. Jersey.

Lee S.H, Lee J-S, Choi YJ and Kim J-G (2009) In situ stabilization of cadmium-,lead-, and zinccontaminated soil using various amendments.Chemosphere 77:1069-1075.

Lindsay, W. L. and Norvell, W. A. (1978). Development of a DTPA soil test for zinc, iron, manganese and copper. Soil Sci.Soc.Amer. J., 42:421-428.

Rickard, D. T. (1974). Kinetics and mechanism of the sulfidation of goethite. Am. J. Sci. 274, 941-952.

Schwertmann, U. and R. M. Cornell(1991). Iron Oxides in the Laboratory - Preparation and Characterization. VCH Verlagsgesellschaft.

Sparks, D. L. (1996). Soil science society of America.; and American society of Agronomy. Methods of soil Analysis . part 3, chemical Methods. Soil Sci. Soc. of Amer. book series, no. 5, Madison.
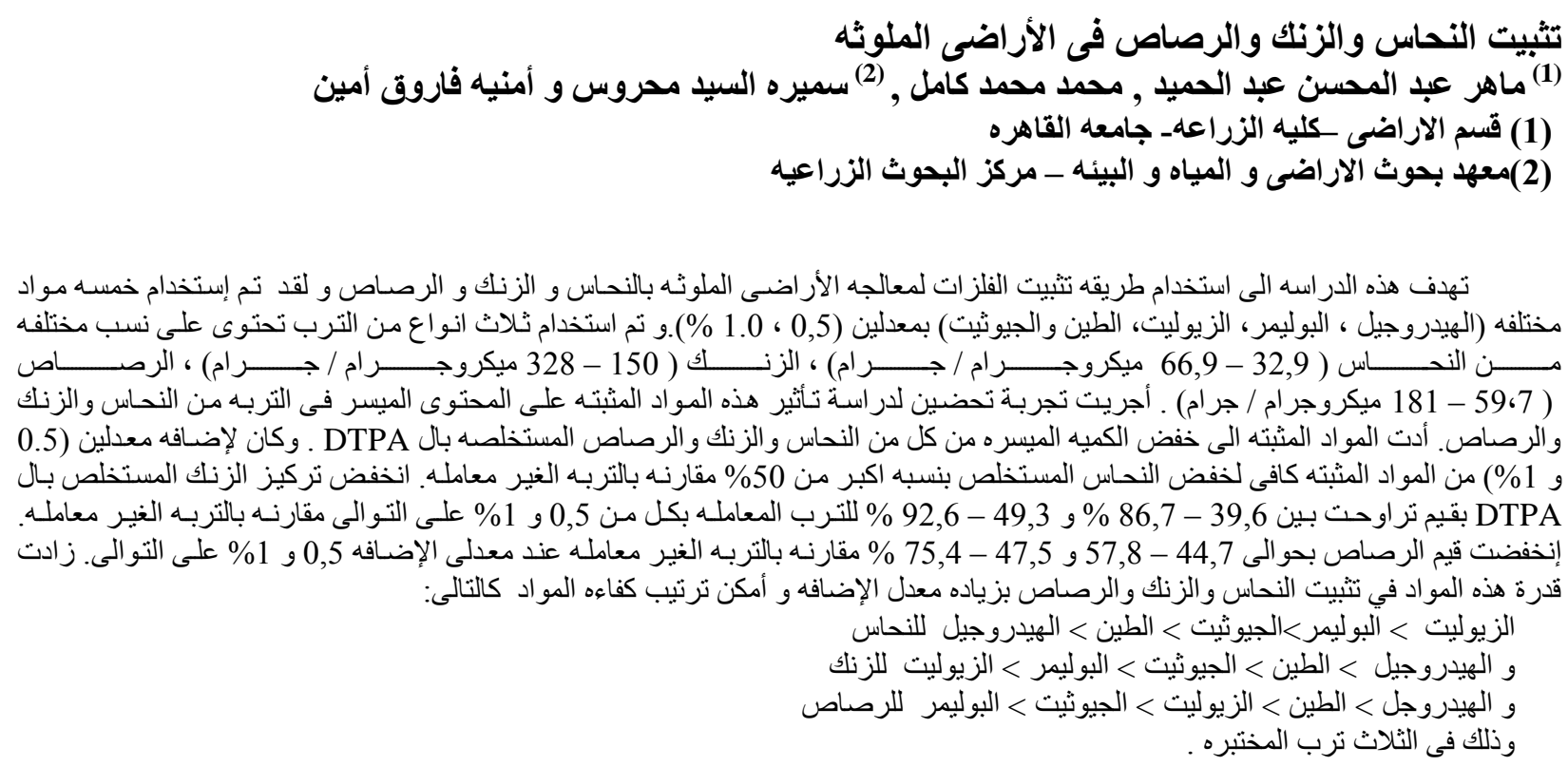
J. Soil Sci. and Agric. Eng., Mansoura Univ., Vol. 7 (3): 273 -279,2016 
J. Soil Sci. and Agric. Eng., Mansoura Univ., Vol. 7 (3): 273 -279,2016 